\title{
First record of Cirrholovenia polynema (Hydrozoa: Leptothecata) in the Western Atlantic Ocean
}

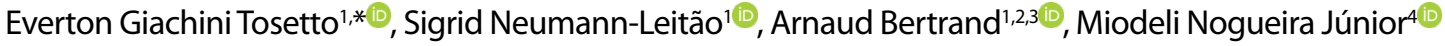 \\ ${ }^{1}$ Departamento de Oceanografia, Universidade Federal de Pernambuco, Avenida Arquitetura, S/N, 50670-901, Recife, PE, Brazil. \\ ${ }^{2}$ Institut de Recherche pour le Développement (IRD), MARBEC, Univ Montpellier, CNRS, Ifremer, IRD, Sète, France \\ ${ }^{3}$ Departamento de Pesca e Aquicultura, Universidade Federal Rural de Pernambuco, Rua D. Manuel de Medeiros, S/N, 52171-900, \\ Recife, PE, Brazil \\ ${ }_{4}^{4}$ Departamento de Sistemática e Ecologia, Universidade Federal da Paraíba, Cidade Universitária, 58051-900, João Pessoa, PB, Brazil \\ *Corresponding author: evertontosetto@hotmail.com
}

Meroplanktonic hydromedusae of the family Cirrholoveniidae Bouillon, 1984 are distinguished from other Leptothecata medusae mainly by the presence of four simple radial canals, marginal cirri, at least four closed statocysts and absence of a gastric peduncle (Bouillon 1999, Bouillon et al. 2006). The genus Cirrholovenia Kramp, 1959 is to date the sole representative of Cirrholoveniidae, presenting characteristics of the family (Bouillon and Boero 2000, Bouillon et al. 2006, Schuchert 2020).

Cirrholovenia was described with the species Cirrholovenia polynema Kramp, 1959 and Cirrholovenia tetranema Kramp, 1959 collected in the Indo-Pacific. The genus was first included in the family Lovenellidae Russell, 1953 (Kramp 1959) and later classified as a new family by Bouillon (1984). Two additional species were described in the genus, Cirrholovenia reticulata Xu \& Huang, 2004 and Cirrholovenia violacea Gershwin, Zeidler \& Davie, 2010, both in the Western Pacific Ocean (Xu and Huang 2004, Gershwin et al. 2010), resulting in four valid species to date (Schuchert 2020).

Hydromedusae are diversified, important predators in marine habitats; information on their distribution is essential for understanding species diversity, biogeographic patterns and marine

Submitted on: 08-August-2020

Approved on: 19-September-2020

Editor: Rubens M. Lopes

2021 The authors. This is an open access article distributed under the terms of the Creative Commons license. ecosystem functioning (Tewksbury et al. 2014, Hays et al. 2018). During two cruises characterizing the zooplanktonic communities from the tropical and equatorial Western Atlantic Ocean (Bertrand 2015, Neumann-Leitão et al. 2018, Tosetto et al. 2019) specimens of $C$. polynema were observed for the first time on the Western side of the Atlantic Ocean. In the present study, we report these occurrences and provide a detailed review of the global distribution of the species along with some insights into the taxonomy of the group.

Specimens were obtained during the "Camadas Finas III" survey conducted in October, 2012, aboard the research vessel NHo. Cruzeiro do Sul H38 (DHN/Brazilian Navy) off North Brazil and the "Acoustics along the Brazilian coast (ABRACOS 1)" survey conducted in October 2015, aboard the French R/V ANTEA off Northeast Brazil (Coordinates: $7.5^{\circ} \mathrm{N}, 46.0^{\circ} \mathrm{W} ; 8.0^{\circ} \mathrm{N}, 42.0^{\circ} \mathrm{W} ; 7.0^{\circ} \mathrm{N}, 38.0^{\circ} \mathrm{W} ; 2.0^{\circ} \mathrm{N}$, $38.0^{\circ} \mathrm{W} ; 3.93^{\circ} \mathrm{S}, 32.52^{\circ} \mathrm{W}$ ). Samples were collected in oblique hauls, using a bongo plankton net with 300 $\mu \mathrm{m}$ mesh and $0.6 \mathrm{~m}$ opening, from near bottom to surface over the continental shelf, and $200 \mathrm{~m}$ depth to surface in open waters. Material was fixed with $4 \%$ formaldehyde buffered with sodium tetraborate $\left(0.5 \mathrm{~g} \mathrm{~L}^{-1}\right)$. Specimens were deposited in the Museu de Invertebrados Paulo Young from Universidade Federal da Paraíba (CIPY1121, CIPY 1124, CIPY 1125).

The seven specimens sampled presented a lenticular umbrella ranging from 2.4 to $6 \mathrm{~mm}$ wide (Fig. $1 \mathrm{a}$; b), with thin mesoglea. The velum is 
broad. Manubrium were large with crenulated lips (Fig. $1 \mathrm{a}$; b). Only one of the specimens presented gonads, which were still developing along the middle of the four radial canals (Fig. 1 b). The two largest species presented 12 fully developed tentacles with heart-shaped bulbs and about two or three rudimentary bulbs between them (Fig. $1 \mathrm{a} ; \mathrm{b})$. Up to eight marginal cirri and one or two closed statocysts distributed between successive tentacles (Fig. $1 \mathrm{c}$ ).

The four radial canals, presence of closed statocysts and marginal cirri, and absence of a gastric peduncle assigned the specimens to the family Cirrholovenidae and genus Cirrholovenia (Bouillon et al. 2006). Among the four currently described species in the genus, $C$. tetranema differs from present specimens by always having four marginal tentacles and no rudimentary bulbs. Its umbrella typically higher than flatter and cylindrical gonads, occupying almost the whole length of the radial canals, also differ in shape and position from our specimens (Kramp 1959, Bouillon et al. 2004; Table 1). C. reticulata also was described with only four marginal tentacles. However, this species was described based on a single small specimen $(0.8 \mathrm{~mm})$ presenting rudimentary bulbs and reticular papillae on the exumbrella (Xu and Huang 2004; Table 1), typically present in recently released medusae (Bouillon et al. 2006). Moreover, considering that only a single small medusa of $C$. reticulata has been described, it is not known whether the rudimentary bulbs will develop tentacles or remain rudimentary as the medusa grows. Thus, $C$. reticulata may be a juvenile of another species, a hypothesis that should be tested pending more specimens to be found and/ or molecular analyses performed. In any case, the present specimens match with C. polynema, which may have up to 20 marginal tentacles, linear gonads along the middle portion of radial canals and up to eight marginal cirri and two statocysts between adjacent tentacles (Kramp 1959; Table 1).

The remaining species of the genus, $C$. violacea, was described with a short and broad gastric peduncle (Gershwin et al. 2010). However, the absence of gastric peduncle is a remarkable characteristic distinguishing Cirrholovenidae from other Leptothecata medusae with closed statocysts such as Lovenellidae, where the genus Cirrholovenia was previously included, and Eirenidae Haeckel, 1879 medusae (Kramp 1959, Bouillon 1984, Bouillon et al. 2006). This issue was apparently overlooked in

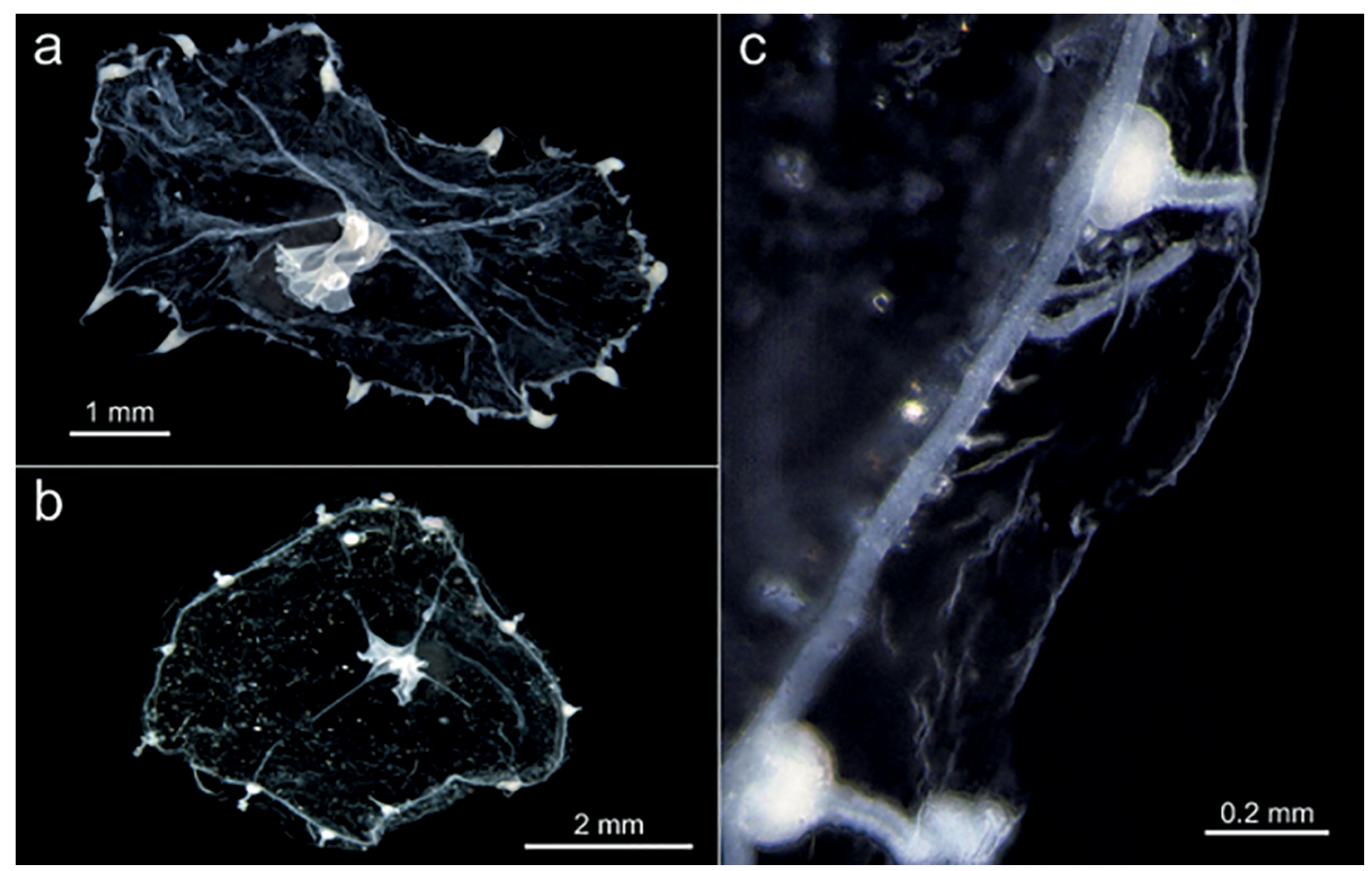

Figure 1. Cirrholovenia polynema medusae from North Brazil. (a and b) Oral view. (c) Detail of bell margin showing statocysts and marginal cirri. 
the $C$. violacea description; it seems likely that the species has been included in the wrong family and genus. Among Eirenidae, the genus Phialopsis Torrey, 1909 include species with a short and broad gastric peduncle, more than 8 statocysts and marginal cirri, matching with the description of the specimen classified as C. violacea. Although it differed in the number of marginal structures and shape of the gonads from the other two known species of Phialopsis (Table 1), the description was based on a small and immature individual that could develop into one of these two species. Further analysis of the material is necessary to elucidate this question.

C. polynema was first described from the Java Sea (Kramp 1959), and is widely distributed in tropical and subtropical areas from the Indo-Pacific, mainly between $30^{\circ} \mathrm{N}$ and $30^{\circ} \mathrm{S}$ (Kramp 1959, 1962, 1965, Bouillon et al. 1986, Du et al. 2012; Fig. 2). Occurrences outside this range also were recorded in temperate areas off New Zealand and Chile (Kramp 1965, Fagetti 1973; Fig. 2). In the Atlantic Ocean the species was only recorded in St. Helena Bay, South Africa (Buecher and Gibbons 2000, Gibbons and Buecher 2001; Fig. 2), this area is under

Table 1. Comparison of main characteristics of the valid medusae species from the genus Cirrholovenia and Phialopsis $\mathrm{NI}=$ Not informed.

\begin{tabular}{|c|c|c|c|c|c|c|}
\hline Species & Bell diameter & Tentacles & \multicolumn{2}{|c|}{ Rudimentary bulbs } & \multicolumn{2}{|c|}{ Marginal cirri } \\
\hline Present specimens & 2.4 to $6 \mathrm{~mm}$ & Up to 12 & \multicolumn{2}{|c|}{$\begin{array}{c}\text { Up to } 3 \text { between successive } \\
\text { tentacles }\end{array}$} & \multicolumn{2}{|c|}{$\begin{array}{c}\text { Up to } 8 \text { between successive } \\
\text { tentacles }\end{array}$} \\
\hline $\begin{array}{l}\text { Cirrholovenia polynema } \\
\text { Kramp, } 1959\end{array}$ & Up to $8 \mathrm{~mm}$ & Up to 20 & & Few & \multicolumn{2}{|c|}{$\begin{array}{c}\text { Up to } 8 \text { between successive } \\
\text { tentacles }\end{array}$} \\
\hline $\begin{array}{l}\text { Cirrholovenia tetranema } \\
\text { Kramp, } 1959\end{array}$ & Up to $1.5 \mathrm{~mm}$ & 4 & & None & \multicolumn{2}{|c|}{$\begin{array}{c}\text { Up to } 8 \text { between successive } \\
\text { tentacles }\end{array}$} \\
\hline $\begin{array}{l}\text { Cirrholovenia reticulate Xu \& } \\
\text { Huang, } 2004\end{array}$ & Up to 0.8 & 4 & \multicolumn{2}{|c|}{1 between successive tentacles } & \multicolumn{2}{|c|}{5 between successive tentacles } \\
\hline $\begin{array}{l}\text { Cirrholovenia (?) violacea } \\
\text { Gershwin, Zeidler \& Davie, } \\
2010\end{array}$ & $1.34 \mathrm{~mm}$ & 12 & \multicolumn{2}{|c|}{ Apparently absent } & \multicolumn{2}{|c|}{ Same number as statocysts } \\
\hline $\begin{array}{l}\text { Phialopsis diegensis Torrey, } \\
1909\end{array}$ & $\mathrm{NI}$ & $16-28$ & \multicolumn{2}{|c|}{$\begin{array}{l}\text { 8-9 between successive } \\
\text { tentacles }\end{array}$} & \multicolumn{2}{|c|}{$\begin{array}{l}\text { More numerous than marginal } \\
\text { papillae }\end{array}$} \\
\hline \multicolumn{7}{|l|}{$\begin{array}{l}\text { Phialopsis averruciformis } \\
\text { Huang, Xu \& Lin, } 2013\end{array}$} \\
\hline & $32 \mathrm{~mm}$ & 52 & & Absent & $3-5 b e$ & $\begin{array}{l}\text { tween successive } \\
\text { tentacles }\end{array}$ \\
\hline Species & \multicolumn{3}{|c|}{ Statocysts } & Gonads & & Reference \\
\hline Present specimens & \multicolumn{3}{|c|}{$\begin{array}{c}1 \text { or } 2 \text { between successive } \\
\text { tentacles }\end{array}$} & \multicolumn{2}{|c|}{$\begin{array}{l}\text { Linear, along the middle of radial } \\
\text { canals }\end{array}$} & This study \\
\hline $\begin{array}{l}\text { Cirrholovenia polynema Kramp, } \\
1959\end{array}$ & \multicolumn{3}{|c|}{ Twice as numerous as tentacles } & \multicolumn{2}{|c|}{$\begin{array}{l}\text { Linear, along the middle of radial } \\
\text { canals }\end{array}$} & Kramp, 1959 \\
\hline $\begin{array}{l}\text { Cirrholovenia tetranema Kramp, } \\
1959\end{array}$ & \multicolumn{3}{|c|}{$\begin{array}{c}1 \text { or } 2 \text { between successive } \\
\text { tentacles }\end{array}$} & \multicolumn{2}{|c|}{$\begin{array}{l}\text { Thick and cylindrical, occupying } \\
\text { almost the whole length of the } \\
\text { radial canals }\end{array}$} & Kramp, 1959 \\
\hline $\begin{array}{l}\text { Cirrholovenia reticulate Xu \& } \\
\text { Huang, } 2004\end{array}$ & \multicolumn{3}{|c|}{1 between successive tentacles } & \multicolumn{2}{|c|}{$\begin{array}{l}\text { Cylindrical, occupying almost the } \\
\text { whole length of the radial canals }\end{array}$} & Xu \& Huang, 2004 \\
\hline $\begin{array}{l}\text { Cirrholovenia (?) violacea } \\
\text { Gershwin, Zeidler \& Davie, } 2010\end{array}$ & \multicolumn{3}{|c|}{3 - 5 between successive tentacles } & \multicolumn{2}{|c|}{ On the middle of radial canals } & $\begin{array}{l}\text { Gershwin et al, } \\
2010\end{array}$ \\
\hline Phialopsis diegensis Torrey, 1909 & \multicolumn{3}{|c|}{2 - 5 between successive tentacles } & \multicolumn{2}{|c|}{$\begin{array}{l}\text { Linear, occupying } 3 / 4 \text { of the distal } \\
\text { portion of radial canals }\end{array}$} & Torrey, 1909 \\
\hline \multicolumn{7}{|l|}{$\begin{array}{l}\text { Phialopsis averruciformis Huang, } \\
\text { Xu \& Lin, } 2013\end{array}$} \\
\hline & \multicolumn{3}{|c|}{$\begin{array}{c}1 \text { or } 2 \text { between successive } \\
\text { tentacles }\end{array}$} & \multicolumn{2}{|c|}{$\begin{array}{l}\text { Linear, extending from the basal } \\
\text { part of peduncle to almost to the } \\
\text { bell margin }\end{array}$} & Wang et al, 2013 \\
\hline
\end{tabular}




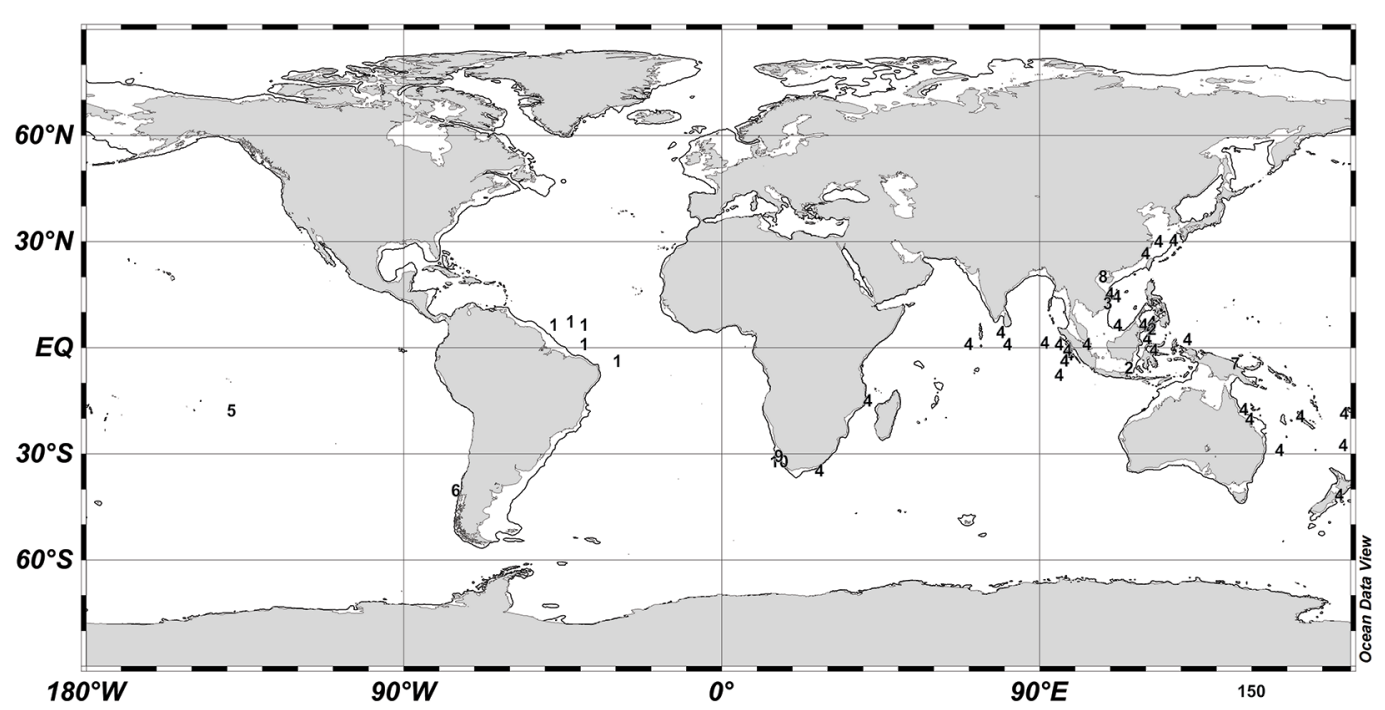

Figure 2. Global distribution of Cirrholovenia polynema based on this study and published records. The continuous line shows the 250-m isobath, roughly corresponding to the shelf break (generated using Ocean Data View software; Schlitzer, 2007). Data Source: $1=$ This study; $2=($ Kramp 1959); $3=($ Kramp 1962); $4=($ Kramp 1965); $5=($ Michel 1969) $; 6=($ Fagetti 1973); $7=($ Bouillon et al. 1986); $8=($ Du et al. 2012$) ; 9=$ (Buecher and Gibbons 2000); $10=$ (Gibbons and Buecher 2001).

influence of the Benguela Current, which is partially fed by the Agulhas Current (Pagès and Gili 1992), coming from the Indian Ocean, thus the presence of the species could be expected there. In this study, we observed $C$. polynema in several locations of the tropical western border of the Atlantic Ocean for the first time, confirming the species is present in the Atlantic far beyond the influence of Agulhas Current in South Africa and ubiquitous to all ocean basins.

Four of the five specimens were collected in tropical open ocean up to $1000 \mathrm{~km}$ away from the coast (surface temperature ranging from 28 to $29.6^{\circ} \mathrm{C}$ and surface salinity ranging from 32.78 to 36.08) and one around the Fernando de Noronha Archipelago $\left(26.6^{\circ} \mathrm{C}\right.$ surface temperature and 36.2 surface salinity). As a meroplanktonic species, many occurrences of $C$. polynema were over the continental shelf (Kramp 1962, 1965, Gibbons and Buecher 2001), where benthic hydroids may easily find substrates for their development. Yet, its presence in offshore areas slightly away from the shelf break and around oceanic islands is not unusual (Kramp 1965, Michel 1969), suggesting the species can potentially inhabit this environment (probably driven by currents) reaching new areas for polyp settlement, and it would justify its wide distribution in tropical and subtropical areas around the world.
Knowledge regarding zooplankton biodiversity in general and cnidarians in particular from the waters off North and Northeast Brazil is scarce (Oliveira et al. 2016, Boltovskoy and Valentin 2018). Thus, the current report contributes not only to the understanding of local biodiversity, but also for and adequate comprehension of global biogeographic and diversity patterns.

\section{ACKNOWLEDGMENTS}

We are grateful to the support of Brazilian National Institute of Science and Technology for Tropical Marine Environments, Brazilian Research Network on Global Climate Change, European Integrated CARBOCHANGE for funding the survey Camadas Finas 3 and the French oceanographic fleet for funding the survey ABRAÇOS 1 and to the officers, crew and scientific team of the Camadas Finas 3 and ABRAÇOS 1 research projects for their contributions to the success of the operations. The present study was not possible without the support of all members from $L A B Z O O$ and other laboratories from UFPE and UFRPE. We thank the CNPq (Brazilian National Council for Scientific and Technological Development), which provided a PhD scholarship to EGT (grant 140897/2017-8) and a Research Scholarship to SNL. 
This work is a contribution to the LMI TAPIOCA (www. tapioca.ird.fr).

\section{AUTHOR CONTRIBUTIONS}

E.G.T: Conceptualization; data curation; formal analysis; investigation; methodology; writing - original draft; writing - review \& editing;

S.N.L.: Conceptualization; funding acquisition; project administration; resources; writing - review \& editing;

A.B.: Conceptualization; funding acquisition; project administration; resources; writing - review \& editing;

M.N.J.: Conceptualization; data curation; formal analysis; investigation; methodology; resources; writing - review \& editing.

\section{REFERENCES}

BERTRAND, A. 2015. ABRACOS cruise, RV Antea. Jean Monnet, CS: French Oceanographic Cruises.

BOLTOVSKOY, D. \& VALENTIN, J. L. 2018. Overview of the history of biological oceanography in the Southwestern Atlantic, with emphasis on plankton. In: HOFFMEYER, M. S., SABATINI, M. E., BRANDINI, F. P., CALLIARI, D. L. \& SANTINELLI, N. H. (eds.). Plankton ecology of the Southwestern Atlantic. New York: Springer Science/Business Media, pp. 3-34.

BOUILLON, J. 1984. Révision de la famille des Phialuciidae (Kramp, 1955) (Leptomedusae, Hydrozoa, Cnidaria), avec un essai de classification des Thecatae-Leptomedusae. IndoMalayan Zoology, 1(1), 1-24.

BOUILLON, J. 1999. Hydromedusae. In: BOLTOVSKOY, D. (ed.). South Atlantic zooplankton. Leiden: Backhuys Publishers, pp. 424-512.

BOUILLON, J. \& BOERO, F. 2000. Synopsis of the families and genera of the hydromedusae of the world, with a list of the worldwide species. Thalasia Salentina, 24, 47-296.

BOUILLON, J., CLAEREBOUDT, M. \& SEGHERS, G. 1986. Hydroméduses de la baie de Hansa (Mer de Bismarck Papouasie NouvelleGuinée) Répartition. Indo-Malayan Zoology, 3(2), 105-152.

BOUILLON, J., GRAVILI, C., PAGÈS, F., GILI, J. M. \& BOERO, F. 2006. An introduction to Hydrozoa. Paris: Publications Scientifiques du Muséum.

BOUILLON, J., MEDEL, M. D., PAGÈS, F., GILI, J. M., BOERO, F. \& GRAVILI, C. 2004. Fauna of the Mediterranean hydrozoa. SCientia Marina, 68(Suppl 2), 5-438.

BUECHER, E. \& GIBBONS, M. J. 2000. Interannual variation in the composition of the assemblages of medusae and ctenophores in St. Helena Bay, Southern Benguela Ecosystem. Scientia Marina, 64(Suppl 1), 123-134.

DU, F. Y., XU, Z. Z., HUANG, J. Q. \& GUO, D. H. 2012. Studies on the medusae (Cnidaria) from the Beibu gulf in the northern South China Sea, with description of three new species. Acta Zootaxonomica Sinica, 37(3), 506-519.
FAGETTI, E. G. 1973. Medusas de aguas chilenas. Revista de Biología Marina, 15(1), 31-75.

GERSHWIN, L., ZEIDLER, W. \& DAVIE, P. J. F. 2010. Medusae (Cnidaria) of Moreton Bay, Queensland, Australia. Memoirs of the Queensland Museum, 54(3), 47-108.

GIBBONS, M. J. \& BUECHER, E. 2001. Short-term variability in the assemblage of medusae and ctenophores following upwelling events in the southern Benguela ecosystem. Marine Ecology Progress Series, 220, 169-177.

HAYS, G. C., DOYLE, T. K. \& HOUGHTON, J. D. R. 2018. A paradigm shift in the trophic importance of jellyfish? Trends in Ecology \& Evolution, 33(11), 874-884.

KRAMP, P. L. 1959. Some new and little-known Indo-Pacific medusae. Videnskabelige Meddelelser fra Dansk Naturhistorisk Forening, 121, 223-259.

KRAMP, P. L. 1962. Medusae of Vietnam. Videnskabelige Meddelelser fra Dansk naturhistorisk Forening i København, 124, 305-366.

KRAMP, P. L. 1965. The hydromedusae of the Pacific and Indian Oceans. Copenhagen: Carlsberg Foundation's.

MICHEL, A. 1969. Plancton du lagon et des abords extérieurs de I'atoll de Mururoa. Cahiers du Pacifique, 13, 81-131.

NEUMANN-LEITÃO, S., MELO, P. A. M. C., SCHWAMBORN, R., DIAZ, X. F. G., FIGUEIREDO, L. G. P., SILVA, A. P., CAMPELO, R. P. S., MELO JÚNIOR, M., MELO, N. F. A. C., COSTA, A. E. S. F., ARAÚJO, M., VELEDA, D. R. A., MOURA, R. L. \& THOMPSON, F. 2018. Zooplankton from a reef system under the influence of the Amazon River plume. Frontiers in Microbiology, 9, 1-15.

OLIVEIRA, O. M. P., MIRANDA, T. P., ARAUJO, E. M., AYÓN, P., CEDEÑO-POSSO, C. M., CEPEDA-MERCADO, A. A., CÓRDOVA, P., CUNHA A. F., GENZANO, G. N., HADDAD, M. A., MIANZAN, H. W., MIGOTTO, A. E., MIRANDA, L. S., MORANDINI, A. C., NAGATA, R. M., NASCIMENTO, K. B., NOGUEIRA JÚNIOR, M., PALMA, S., QUIÑONES, J., RODRIGUEZ, C. S., SCARABINO, F., SCHIARITI, A., STAMPAR, S. N., TRONOLONE, V. B. \& MARQUES, A. C. 2016. Census of Cnidaria (Medusozoa) and Ctenophora from South American marine waters. Zootaxa, 4194(1), 1-256.

PAGÈS, F. \& GILI, J. M. 1992. Influence of Agulhas waters on the population structure of planktonic Cnidarians in the southern Benguela Region. Scientia Marina, 56(2-3), 109-123.

SCHUCHERT, P. 2020. WORMS - World register of marine species [online]. Belgium: Flanders Marine Institute. Available at: http://www.marinespecies.org [Accessed: 08/01/2020].

TEWKSBURY, J. J., ANDERSON, J. G. T., BAKKER, J. D., BILLO, T. J., DUNWIDDIE, P. W., GROOM, M. J., HAMPTON, S. E., HERMAN, S. G., LEVEY, D. J., MACHNICKI, N. J., DEL RIO, C. M., POWER, M. E., ROWELL, K., SALOMON, A. K., STACEY, L., TROMBULAK, S. C. \& WHEELER, T. A. 2014. Natural history's place in science and society. BioScience, 64(4), 300-310.

TOSETTO, E. G., NEUMANN-LEITÃO, S. \& NOGUEIRA JÚNIOR, M. 2019. Sampling planktonic cnidarians with paired nets: implications of mesh size on community structure and abundance. Estuarine, Coastal and Shelf Science, 220, 48-53.

XU, Z. \& HUANG, J. 2004. On new species and record of Laingiomedusae and Leptomedusae (Cnidaria, Hydrozoa, Hydroidomedusae) in the Taiwan strait. Journal of Xiamen University (Natural Science), 43(1), 107-114. 